\title{
Freshwater-salt water interface dynamics during pumping tests
}

\section{Dinamica dell'interfaccia acqua dolce - acqua salata durante prove di emungimento}

\author{
Yongcheol Kim, Heesung Yoon, Soo-Hyung Lee
}

Riassunto: L'individuazione della superficie di separazione tra acqua dolce e acqua salata è un' informazione importante per chi si occupa di gestione delle risorse idriche sotterranee in ambito costiero, tuttavia le sue oscillazioni nel tempo sono sempre state difficili da conoscere attraverso metodi convenzionali, quali il monitoraggio della conducibilità elettrica a profondità stabilite, indagini geofisiche e tecniche di telerilevamento.

Un rilevatore di cuneo salino, in grado di posizionarsi, in base alla sua densità, nell'interfaccia tra acqua dolce e acqua salata e di muoversi con essa in base alle sue oscillazioni, è stato usato per determinare le sue variazioni della posizione nel tempo durante diverse prove di emungimento, che sono state effettuate in pozzi di monitoraggio nella località di Seocheon, nell'area centro occidentale della penisola Coreana.

Sono stati effettuate quattro prove di emungimento di breve durata, tre di lunga durata, un test a unico gradino in abbassamento, un test ad unico gradino in risalita, con pompaggi che variavano dai 19.86 ai $48.71 \mathrm{~m}^{3} /$ giorno e periodi di pompaggio che variavano da 60 a 2851 minuti.

Keywords: Freshwater-salt water interface (FSI), Interface-Egg, pumping test, salt water up-coning, Seocheon (Korea).

Parole chiave: Interfaccia acqua dolce e salata; sonda di interfaccia; prove di emungimento, intrusione salina, Seocheon (Korea).

\section{Heesung YOON 莑”}

Korea Institute of Geoscience and Mineral Resources,

124 Gwahang-no, Yuseong-gu, Daejeon, Republic of Korea

hyoon@kigam.re.kr

\section{Yongcheol KIM}

Soo-Hyung LEE

Korea Institute of Geoscience and Mineral Resources,

124 Gwahang-no, Yuseong-gu, Daejeon, Republic of Korea

Ricevuto/Received: 04 March 2019-Accettato/Accepted: 15 March 2019 Pubblicato online/Published online: 29 March 2019

This is an open access article under the CC BY-NC-ND license: http://creativecommons.org/licenses/by-nc-nd/4.0/

(C) Associazione Acque Sotterranee 2019
I dati mostrano come la sonda di interfaccia sia salita da -86.0 a $-77.6 \mathrm{~m}$ slm dopo 24 ore di pompaggio e a $-40.8 \mathrm{~m}$ slm dopo due giorni, e lo spessore della lente d'acqua dolce si sia ridotto da $88.1 \mathrm{~m}$ a $78.4 \mathrm{~m}$ dopo 24 ore e successivamente a $42.3 \mathrm{~m}$ dopo 2 giorni di pompaggio.

I dati mostrano come la risalita dell'acqua salata nel pozzo di emungimento avvenga molto rapidamente e recuperi con un tempo molto più lungo, con un tasso di circa $1.5 \mathrm{~cm} /$ giorno e impiegando fino a 3 mesi dopo lo stop del pompaggio.

Viene anche mostrato dai dati del carico idraulico e dalla localizzazione delle sonde di interfaccia, come ci sia una influenza delle maree durante i periodi di emungimento.

La sonda di interfaccia si pensa possa essere applicata nella pratica, alla gestione degli acquiferi costieri per prevenire l'intrusione salina, specialmente in zone dove sono presenti diversi pozzi di emungimento per l'approvvigionamento idrico domestico e/o agricolo.

Abstract: Freshwater-salt water interface (FSI) location is very important information for decision maker in managing coastal aquifer system, however, its temporal change have been hard to get using conventional method such as EC monitoring at one or several fixed depths, geophysical logging or remote sensing techniques. A FSI tracking device, which has density between freshwater and salt water and hence can moves up and down as the freshwater-salt water transition zone moves, is used to get a temporal change data for the interface during several different types of pumping tests, which were performed at coastal monitoring wells in Seocheon, middle west of Korean Peninsula. Four short period pumping tests, three long-period pumping tests, one step-drawdown test, one reverse step-drawdown test were performed at different pumping rate ranging 19.86 to $48.71 \mathrm{~m}^{3} / d$ for different pumping period of 60 minutes to 2851 minutes. Time series data shows that the Interface-Egg rises up from -86.0 to $-77.6 \mathrm{~m}$ amsl after 24-hours pumping and to -40.8 m amsl after 2-days pumping and freshwater lens thickness is getting thinner from $88.1 \mathrm{~m}$ to $78.4 \mathrm{~m}$ after 24-hours pumping and then $42.3 \mathrm{~m}$ after 2-days pumping. These salt water up-coning phenomena are supported by EC profiles which were logged before and after the whole pumping periods. Time series data tell us that salt water upconing in the pumping well happens quickly and recovers at a very slow rate which is about $1.5 \mathrm{~cm} / \mathrm{d}$ at 3 months after stopping pumping. The time series data of groundwater head and the interface-Egg's location also shows that there is a tidal influence between pumping periods. The FSI tracker is expected to be practically applied to coastal aquifer management preventing from salt water intrusion, especially at dynamically pumping area for agricultural andlor domestic water supply. 


\section{Introduction}

Coastal aquifers in many places are becoming hard to manage under the condition of the growing prospects of global climate change, increasing population in coastal area and excessive pumping activity. These areas are vulnerable to groundwater contamination by saltwater intrusion. The monitoring of temporal change in the location of the FSI including the groundwater level (GWL) is the essential information for effective management of coastal aquifer, especially for managing the saltwater intrusion (Kim et al. 2016).

There have been a plenty of researches on detecting FSI and characterizing transition zone in coastal aquifer. There are several detecting methods of FSI at coastal aquifer such as periodical logging for vertical EC profile (Kim et al. 2006; Liu and Dai 2012) and/or geochemical water sampling to measure the salinity at several depths (Vengosh el al. 1999; Garing et al. 2013). These methods can give us information on the snap-shot of the vertical profile of FSI are not efficient in finding out the temporal trend of the FSI, especially under the dynamically changing condition. Automatic observation equipment has been widely used for the long-term monitoring by measuring water pressure, temperature and/or electrical conductivity at a certain depth in the well. However, those automatic sensors, even in case of being installed at several depths in a monitoring well, can only give us the information that the FSI is either above or below the sensor.

There are also indirect methods such as geophysical techniques including direct current-resistivity method (Fretwell and Stewart 1981; Pidllisecky et al. 2015) and electromagnetic method (Ong et al. 2010) and pressure analysis method (Kim et al. 2007), in which pressure sensors are installed both in freshwater and saltwater. The geophysical methods can provide information of large area (Melloul and Goldenberg 1997), however those have inherently high uncertainties because the relation of measured signal and salinity is approximate and the measured signal can be affected by other environmental factors as well as salinity (Werner et al. 2013).

It is necessary to monitor the location of FSI and its temporal variation exactly for the reliable and effective management of groundwater resources in coastal areas, especially under dynamic conditions such as high tidal fluctuation and nearby pumping activities. In this study, new FSI tracking equipment (hereafter calls this as Interface-Egg) (Kim et al. 2016) is applied and validated to monitor temporal change of the interface for detecting salt water up-coning and recovery during and after pumping activities.

\section{Methods and study site Study site}

The study site is located at Seocheon, Choongnam Province, Korea where is in lower middle part of western coastal area of Korean peninsula (Fig 1). The study site faces the Yellow sea on the west and mud flat is widely developed in this area. The tides in this area are semidiurnal and their range is from 4 to 8 meters in height along the coast with a maximum spring

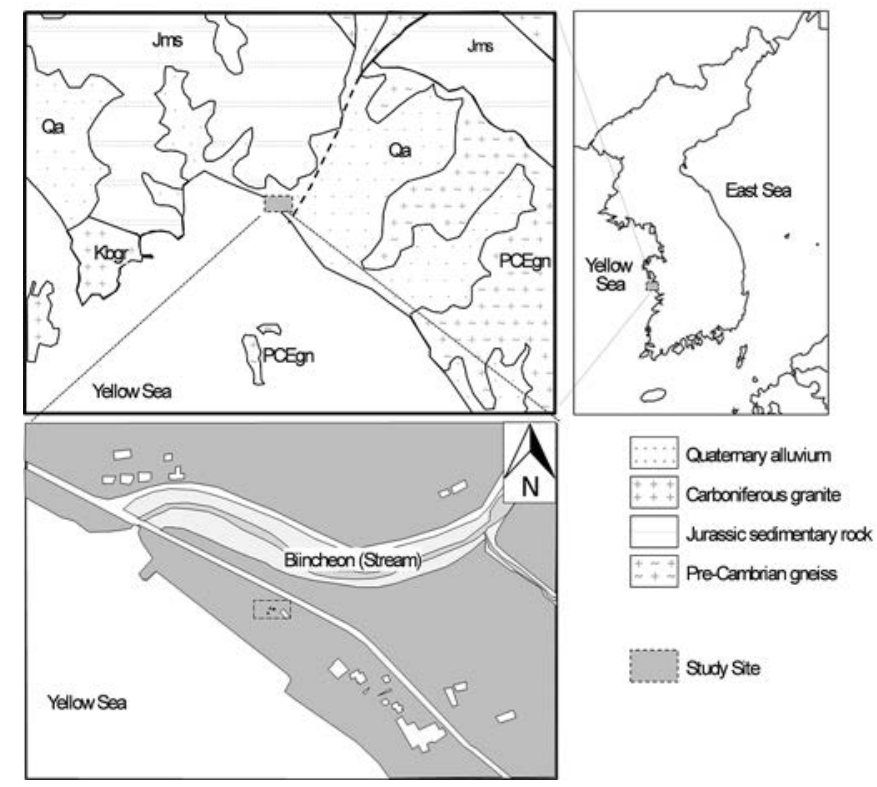

Fig. 1 - Location map and the geologcial map of the study site, Seocheon, Choongnam Province, Korea.

Fig. 1 - Localizzazione dell'area e carta geologica dell'area di studio, Seocheon, Provincia di Choongnam, Korea.

tide of almost 8.2 meters. The study site is about $60 \mathrm{~m}$ distant from the shoreline at high tide and about $1 \mathrm{~km}$ distance at low tide because of high range of tidal fluctuation and flat sea floor. Generally, the climate is characterized by cold, dry winters and wet, warm summers.

According to geological map of this area, Quaternary alluvium is overlying Carboniferous granite which is underlain by Jurassic sedimentary rock and Pre-Cambrian gneiss (Fig.1). The geological cross section based on the cores collected in the monitoring wells shows that the Jurassic sedimentary rock underlies the Pre-Cambrian gneiss being underlain by the Quaternary alluvium of about $15.5 \mathrm{~m}$ thick (Fig. 2). The Quaternary alluvium is consisting of sand, gravel, silty clay and silty sand from the surface with thickness of $5 \mathrm{~m}, 4 \mathrm{~m}$, $4.5 \mathrm{~m}$ and $2 \mathrm{~m}$, respectively. The Jurassic sedimentary rock is shale and sandstone with $15.5 \mathrm{~m}$ thickness in this site.

There are three monitoring wells and the distance between the monitoring well $1(\mathrm{MW} 1)$ and the monitoring well 2 (MW2) is $10 \mathrm{~m}$. The distance between MW1 and the monitoring well 3 (MW3) is $7 \mathrm{~m}$ and MW2 is $5 \mathrm{~m}$ apart from MW3. Borehole depths are $100 \mathrm{~m}, 150 \mathrm{~m}$ and $30 \mathrm{~m}$ for MW1, MW2 and MW3, respectively. The borehole diameter is $0.15 \mathrm{~m}$ for MW1 and MW3 and $0.1 \mathrm{~m}$ for MW2. All the monitoring wells are full screened with PVC pipe except the cased part of upper $15.5 \mathrm{~m}$ below the ground surface at MW1 and MW3. Borehole of MW2 was cased $5 \mathrm{~m}$ below the ground surface.

\section{Pumping tests and monitoring method}

The temporal change of tide, precipitation, GWL and FSI location were monitored during July 1 st to October $5^{\text {th }}$, 2016 to check natural trend without artificial events such as 


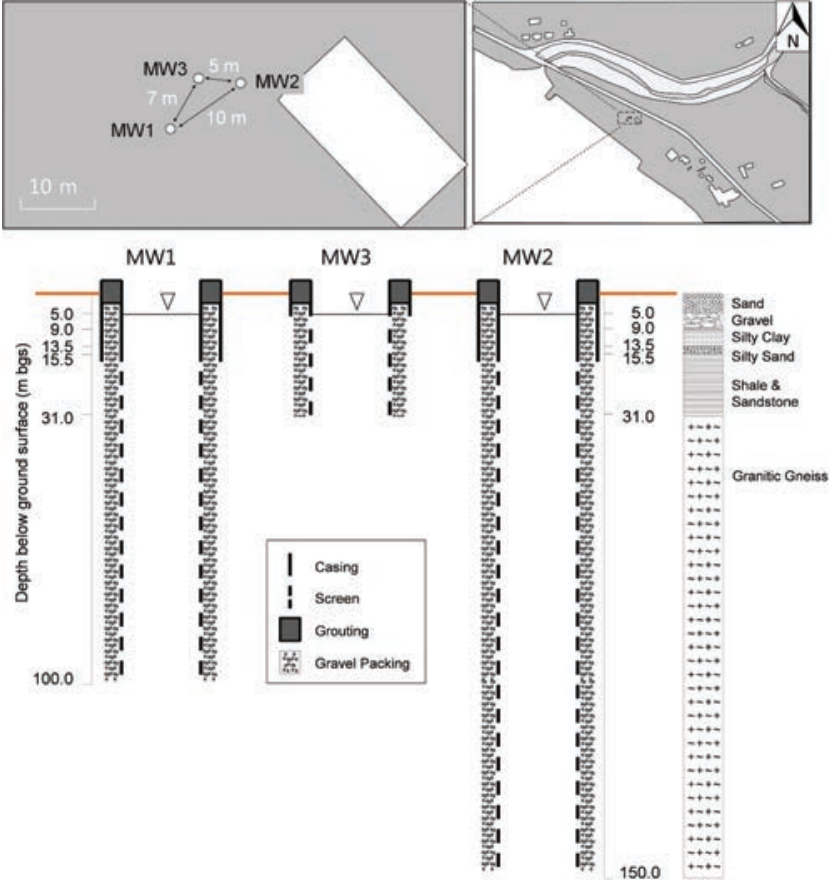

Fig. 2 - Well configuration and geological cross section of the monitoring wells. The white rectangles represents houses.

Fig. 2 - Configurazione e sezione geologica dei pozzi di monitoraggio. I rettangoli bianchi rappresentano degli edifici.

pumping. Tidal data was obtained from the nearest station of Seocheon-Maryang served by Korea National Oceanographic Research Institute and precipitation data were obtained from the nearest station of Choonjangdae served by Korea meteorological Administration. GWL and FSI location data were obtained using an auto-logging pressure sensor, a barometric sensor and Interface-Egg.

Total 9 different types of pumping tests such as longterm constant rate test, variable rate test, step drawdown test, reverse step test and interval test are performed from June $14^{\text {th }}$ to July $4^{\text {th }}, 2017$ which is summarized at Table 1. Pumping rate ranges from 28.09 and $48.71 \mathrm{~m}^{3} / \mathrm{d}$ and total pumping time ranges from 60 minutes to 2851 minutes.

MW1 is pumping well and MW1 and MW2 is used as observation well for head drawdown and FSI location. Interface-Egg was installed in MW1 at the first stage and submersible pump was equipped at the depth of $50 \mathrm{~m}$ from the top of casing in MW1. Because the detailed description on the installation method of the Interface-Egg and estimation method of FSI location using Interface-Egg data is described in Kim et al. (2016), the details are not described here. Autologging sensors, which can measure pressure, temperature and $\mathrm{EC}$, are installed at MW1 and MW2. Barometric pressure sensor was installed at the top part of casing. Flow rate was measured using flowmeter attached to the discharge pipe.

To have snap-shots of vertical EC profiles, EC logging was performed about 27 hours before the first pumping test and about 7 hours later the last pumping test by another autologging sensor (pressure/EC/temperature). And then vertical EC profiles are logged at 64 days, 100 days and 189 days later.

\section{Results and discussion Temporal change before pumping events}

The temporal change of tide, precipitation, GWL and FSI location was monitored during July 1 st to October $5^{\text {th }}$, 2016 is shown at figure 3. Tidal fluctuation shows well semidiurnal and semimonthly frequency with highest tide of 7.43 and lowest tide of $0.39 \mathrm{~m}$ above mean sea level. GWL is fluctuating under the influence of tidal fluctuation and rainwater recharge. FSI location is slightly affected by semidiurnal tidal fluctuation but does not seem to be affected by individual precipitation events.

\section{Temporal change during pumping events}

Temporal changes of GWL, FSI location and freshwater lens thickness during the nine pumping events are plotted in the figure 4. Time series data shows that the Interface-Egg rises up from -86.0 to $-77.6 \mathrm{~m}$ above mean sea level after the pumping test no. 2 (24-hours pumping) and to $-40.8 \mathrm{~m}$ above mean sea level after the pumping test no. 3 (2-days pumping). At the same time freshwater lens thickness is getting thinner from $88.1 \mathrm{~m}$ to $78.4 \mathrm{~m}$ after the pumping test no. 2 and then to $42.3 \mathrm{~m}$ after the pumping test no. 3. Whereas GWL did recover fast to its original location right after all the tests,

Tab. 1 - Summaries of various types of pumping tests performed in the study site.

Tab. 1 - Sintesi dei vari tipi di prova di emungimento realizzati nel sito.

\begin{tabular}{|c|c|c|c|c|}
\hline $\begin{array}{l}\text { Test } \\
\text { No. }\end{array}$ & $\begin{array}{c}\text { Pumping period } \\
\text { (yyyy.mm.dd hh:mm) }\end{array}$ & $\begin{array}{l}\text { Total pumping time } \\
\text { (min) }\end{array}$ & Test types & $\begin{array}{l}\text { Pumping rate } \\
\qquad\left(\mathrm{m}^{3} / \mathrm{d}\right)\end{array}$ \\
\hline 1 & 2017.06.14 17:00 - 2017.06.14 23:00 & 360 & Step test & $19.86 / 33.97 / 42.06 / 47.28$ \\
\hline 2 & 2017.06.15 16:00 - 2017.06.16 16:02 & 1442 & Variable rate & $40.75 \sim 35.42$ \\
\hline 3 & 2017.06.19 18:30 - 2017.06.21 18:01 & 2851 & Constant rate & 30.15 \\
\hline 4 & $2017.06 .2214: 30$ - 2017.06.22 20:00 & 300 & Reverse step test & $40-11$ \\
\hline 5 & 2017.06 .23 18:00 - 2017.06.23 20:10 & 120 & Variable rate & $48.71 \sim 39.45$ \\
\hline 6 & 2017.06.26 17:00 - 2017.06.26 20:03 & 183 & Constant rate & $28.09 \sim 24.93$ \\
\hline 7 & 2017.06.28 13:00 - 2017.06.28 18:00 & 60 (3 times) & Interval test & 43 \\
\hline 8 & 2017.06.29 14:30 - 2017.06.29 17:30 & 180 & Constant rate & 45 \\
\hline 9 & 2017.07.03 20:00 - 2017.07.04 11:00 & 900 & Constant rate & 38 \\
\hline
\end{tabular}




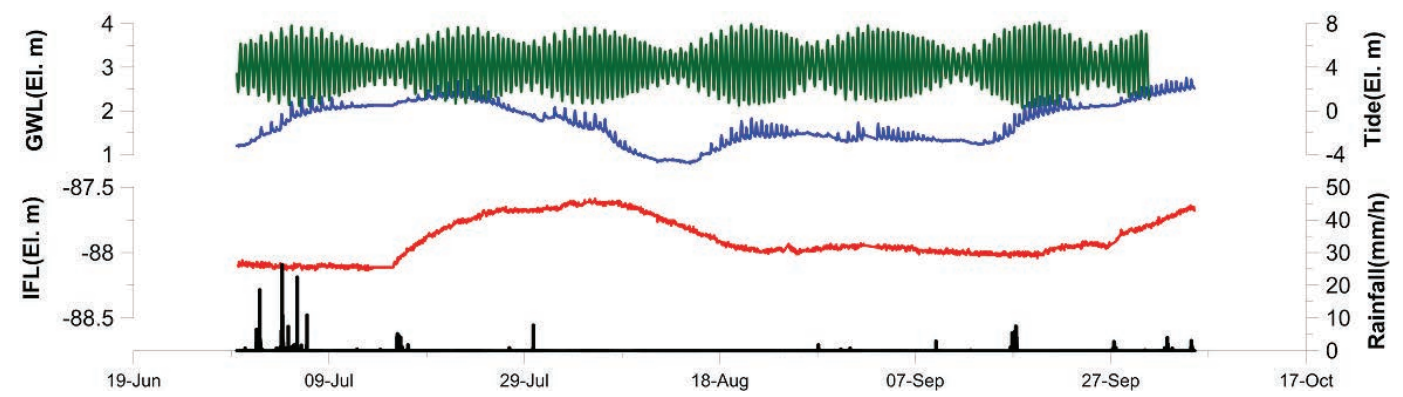

Fig. 3 - Temporal change of Tide, precipitation, GWL and interface location of freshwater-salt water (IFL) without artifcial pumping events during July 1 st to October $5^{\text {th }}$, 2016 at the study site.

Fig. 3 - Dati di, marea, precipitazioni, livello di falda e quota interfaccia acqua dolce - acqua salata, in assenza di emungimenti nel periodo 1 luglio - 5 ottobre 2016 nell'area di studio.

slightly fluctuating by tidal influence between pumping events. The fluctuation pattern of the Interface-Egg at the turn-on and turn-off moment of the submersible pump is showing instant sinking and recovery at moment of pumpon and instant rising and recovery at the moment of pumpoff due to oscillating phenomenon happened to a centrifugal pump impeller.

Time series data of the Interface-Egg location in figure 4 tell us that salt water up-coning in the pumping well happens quickly and recovers at a very slow rate. The recovery rate calculated using time series data of the Interface-Egg location is about $1.5 \mathrm{~cm} / \mathrm{d}$ at 3 months after stopping pumping even though the data is not shown here.

\section{Change in EC profiles before and after the events}

Vertical EC profiles shows dramatic snap-shot of the salt water up-coning in the pumping well and very slow recovery to its original profile (Fig. 5). The EC profile logged at 6.7 hours after the last pumping test on July $4^{\text {th }}, 2017$ shows widely-dispersed and stair-shaped transition zone. It cannot be known that when these shape of transition zone started to form because EC profile was not logged during the pumping events due to the pumping equipment in the borehole, but we could say that salt water up-coning in the pumping well can be accelerated by vertical dispersion.
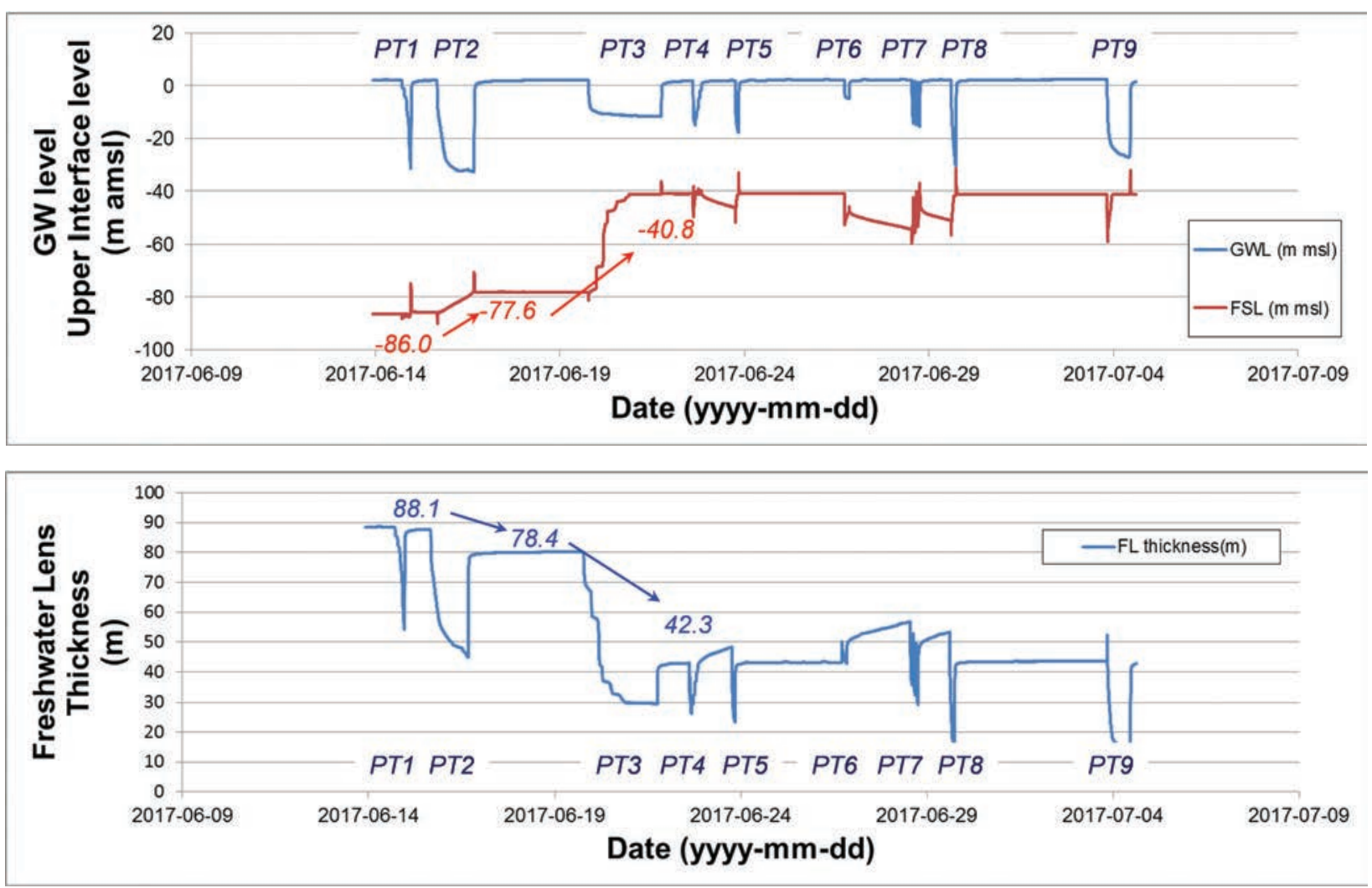

Fig. 4 - Temporal change of GWL, FSI location and freshwater lens thickness at the MW1 during the various types of pumping events.

Fig. 4 - Dati di livello falda, quota interfaccia acqua dolce - acqua salata e spessore della lente di acqua dolce nel pozzo MW1 durante vari tipi di eventi di pompaggio. 


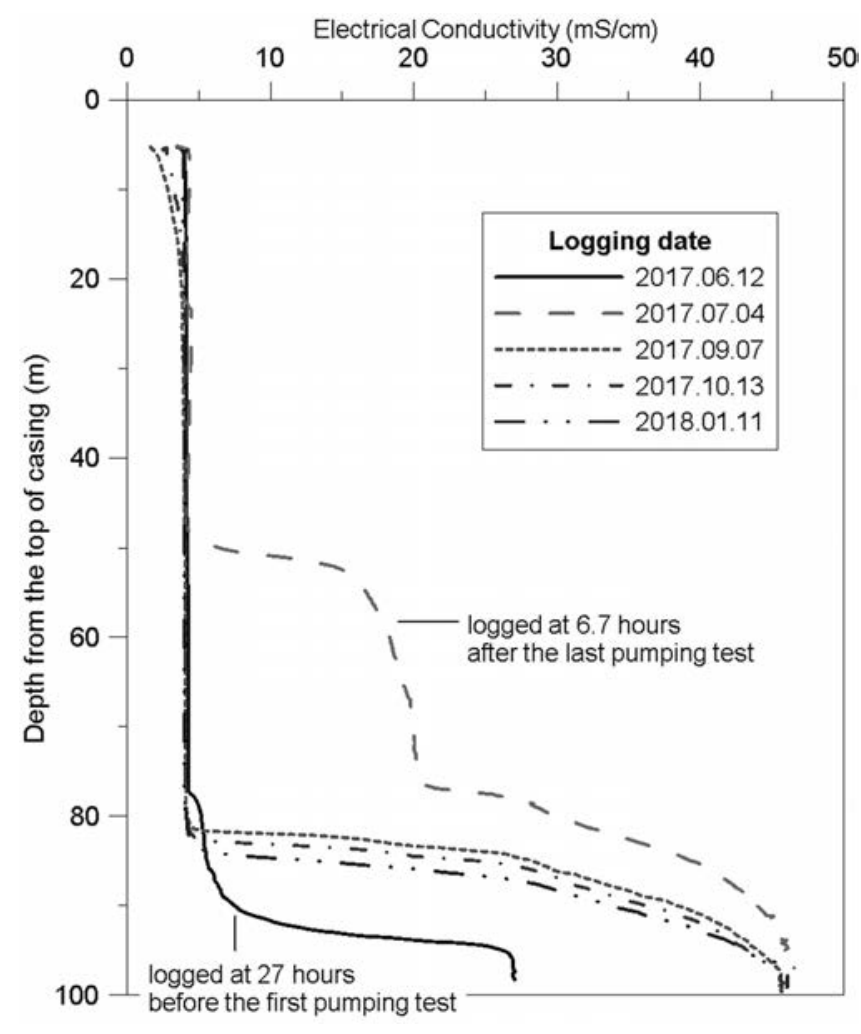

Fig. 5 - Vertical EC profiles logged before and after the whole pumping periods.

Fig. 5 - Log verticali di conducibilità elettrica registrati prima e dopo tutte le prove di emungimento.

\section{Conclusions}

The Interface-Egg was successfully applied to pumping well to monitor the temporal change of the FSI location during the dynamic conditions influencing by pumping and tide. The temporal change of FSI location provides information that the salt water up-coning happens at least by 24-hours or longer period pumping events in this site under the pumping rate ranging about $20-48 \mathrm{~m}^{3} / \mathrm{d}$. These salt water up-coning phenomena are supported by EC profiles which were logged before and after the whole pumping periods. It is confirmed from results of these field experiments that the up-coning by pumping activity in the well could be accelerated by vertical dispersion and its recovery rate is much slower than that of the up-coning.

The Interface-Egg can download data from the sensor attached to the body after monitoring period, which can collect time series data on the FSI location but cannot provide us the data in real time due to technical limitation. Although we cannot get the data on the FSI location in real time, which are important to predict and manage the coastal aquifer, the collected temporal data of passed period on the FSI location are still useful to understand coastal aquifer dynamic when used with other data set such as EC profile, GWL, tide, precipitation and so on.

\section{REFERENCES}

Fretwell JD, Stewart MT (1981) Resistivity study of a coastal karst terrain, Florida. Ground Water 19: 156-162.

Garing C, Luquot L, Pezard PA, Gouze P (2013) Geochemical investigations of saltwater intrusion into the coastal carbonate aquifer of Mallorca, Spain. Appl Geochem 39: 1-10.

Kim KY, Chon CM, Park KH (2007) A simple method for locating the fresh water-salt water interface using pressure data, Groundwater 45(6):723-728.

Kim Y, Yoon H, Kim GP (2016) Development of a novel method to monitor the temporal change in the location of the FSI and time series models for the prediction of the interface, Environmental Earth Science 75:882.

Liu CK, Dai JJ (2012) Seawater intrusion and sustainable yield of basal aquifers. J Am Water Resour Assoc 48(5): 861-870.

Melloul AJ, Goldenberg LC (1997) Monitoring of Seawater Intrusion in Coastal Aquifers Basics and Local Concerns. J Environ Manage 51: 73-86.

Ong JB, Lane JW, Zlotnik VA, Halihan T, White EA (2010) Combined use of frequency domain electromagnetic and electrical resistivity surveys to delineate nearlake groundwater flow in the semi-arid Nebraska Sand Hills, USA. Hydrogeol J 18: 1539-1545.

Pidllisecky A, Moran T, Hansen B, Knight R (2015) Electrical Resistivity Imaging of Seawater Intrusion into the Monterey Bay Aquifer System. Groundwater(articles in press).

Vengosh A, Spivack AJ, Artzi Y, Ayalon A (1999) Geochemical and boron, strontium, and oxygen isotopic constraints on the origin of the salinity in groundwater from the Mediterranean Coast of Israel. Water Resour Res 35:1877-1894.

Werner AD, Bakker M, Post VEA, Vandenbohede A, Lu C, AtaieAshtiani B, Simmons CT, Barry DA (2013) Seawater intrusion processes, investigation and management: Recent advances and future challenges. Adv Water Resour 51: 3-26.

Yoon H, Kim Y, Ha K, Lee SH, Kim GP (2017) Comparative evaluation of ANN- and SVM-time Series models for predicting freshwater-saltwater interface fluctuations, Water 9(5):323.

Acknowledgment: This research was supported by the Basic Research Project(19-3411) of the Korea Institute of Geoscience and Mineral Resources and the Korea Ministry of Environment(MOE) as "Demand Responsive Water Supply Service Program(RE201901097)”. 